\title{
Use of management indicators in the San Francisco de los Romo industrial park
}

\section{Uso de indicadores gerenciales en el parque industrial de San Francisco de los Romo}

VAZQUEZ-GUTIERREZ, Rosa Inés†*, FLORES-AGUILAR, Mauricio and ARELLANO-YAÑEZ, Ricardo

Universidad Tecnologica del Norte de Aguascalientes, Mexico.

ID $1^{\text {st }}$ Author: Rosa Inés, Vazquez-Gutierrez / ORC ID: 0000-0001-8774-7737, Researcher ID Thomson: X-2867-2018.

ID $1^{\text {st }}$ Coauthor: Mauricio, Flores-Aguilar / ORC ID: 0000-0003-0846-3803, Researcher ID Thomson: X-2169-2018.

ID $2^{\text {nd }}$ Coauthor: Ricardo, Arellano-Yañez / ORC ID: 0000-0003-3589-8255, Researcher ID Thomson: X-3077-2018.

DOI: $10.35429 /$ JMPC.2020.18.6.22.32

Received: July 10; Accepted: December 30, 2020

\begin{abstract}
This research is the result of 3 investigations carried out in three of the main Industrial Parks of the state of Aguascalientes, Mexico. The industrial parks on which this research is based are the San Francisco de los Romo Park, the Industrial Park of the Aguascalientes Valley, known as PIVA and the Santa Clara Park. The purpose of this paper is to investigate which are the Management Indicators used by the Automotive companies in the Industrial Park of San Francisco de los Romo. The most important aspects of the companies they incur in implementing the management indicators of the areas of:
\end{abstract}

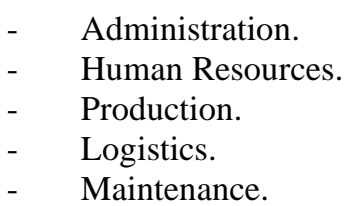

KPI, Management Indicators, Automotive Industry, Aguascalientes

\section{Resumen}

Esta investigación es el resultado de 3 investigaciones realizadas en tres de los principales Parques Industriales del estado de Aguascalientes, México. Los parques industriales en los cuales se basa esta investigación son el San Francisco de los Romo, el Parque Industrial del Valle de Aguascalientes, conocido como PIVA y el Parque Santa Clara. El presente trabajo tiene como objeto investigar cuales son los Indicadores Gerenciales que utilizan las empresas Automotrices en el Parque Industrial San Francisco de los Romo. Se analiza los aspectos más importantes de las empresas en los que incurren al implementar los indicadores gerenciales de las áreas de:

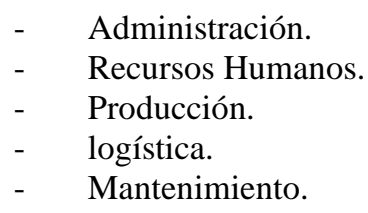

KPI, Indicadores Gerenciales, Industria Automotriz, Aguascalientes

Citation: VAZQUEZ-GUTIERREZ, Rosa Inés, FLORES-AGUILAR, Mauricio and ARELLANO-YAÑEZ, Ricardo. Use of management indicators in the San Francisco de los Romo industrial park. Journal of Microfinance Planning and Control. 2020. 6-18:22-32.

\footnotetext{
* Correspondence to the Author (Email: rosa.vazquez@utna.edu.mx)

$\dagger$ Researcher contributing as first author.
} 


\section{Introduction}

This report presents an analysis of the use of Managerial Indicators in automotive companies in the San Francisco de los Romo Industrial Park.

A survey was carried out to analyze the use of these Indicators, here the necessary questions were formulated to contemplate the most important KPI's within an automotive company.

The areas of the companies where the use of indicators was contemplated are:

- Administration.

- Human Resources.

- Production.

- Logistics.

- Maintenance.

The results of the survey applied to a sample of 4 companies from a universe of 1 company that correspond to $36 \%$ of the automotive industry in said park are shown below.

This project benefits the automotive and metal mechanical industries as it allows us to know what the strengths and weaknesses are regarding the use of these indicators in this industrial park.

\section{Methodology}

According to Hernández Sampieri (2010) the study that was applied was a "Quantitative Exploratory" study where a survey-type data recovery tool will be used.

\section{Sampling}

The type of sampling that was carried out was stratified. The advantage of this type of sampling is that it tends to ensure that the sample adequately represents the population based on selected variables. It also allows obtaining more precise estimates and its objective is to obtain a sample that is as similar as possible to the population in terms of the stratified variable(s).
The result was a sample of 4 companies out of 11 registered as automotive companies. Which represents $36 \%$ of the companies that could be explored.

\begin{tabular}{|ll|}
\multicolumn{2}{|l|}{$\begin{array}{c}\text { Automotive companies in the industrial park of } \\
\text { San Francisco de los Romo Aguascalientes }\end{array}$} \\
\hline- & San-s Mexicana SA de CV. \\
\hline- & K\&S Mexicana Harness Systems. \\
\hline- & Gestamp México SA de CV. \\
\hline- & Kotobukiya Treves from Mexico. \\
\hline- & Sacred Mexicana SA de CV. \\
\hline- & Calsonic Kansei. \\
\hline- & Mabuchi Motor. \\
\hline- & Suncall. \\
\hline- & Sumimoto. \\
\hline- & ITW Automotive Products México SA de CV. \\
\hline
\end{tabular}

\section{Background}

Currently, to measure and improve their processes, companies use statistical measures based on the objective of evaluating the performance of an organization, a system or a process through indicators. The evolution of the concept of metrics in quality management, as explained by Professor Michael A. Noble of the University of British Columbia, has been radically transformed in recent decades.

The dates of how the stages for the development of an indicator were named are listed below.

1920: plan - do - see (Walter A. Shewart).

1940: plan - do - check - take action (J. Edwards Deming).

1980: define - measure - analyze improve - control (Bob Galvin).

Today: normalization. The era of ISO 9001 quality indicators and the rest of the families.

Companies must determine, collect and analyze the appropriate data to demonstrate the adequacy and efficiency of the quality management system and assess where it is necessary to apply continuous improvement to optimize their processes. For this it will mainly measure: efficiency, effectiveness and productivity, based on ISO 9001: 2015. 
The elementary information that this normative framework offers us is that they limit efficiency as the degree to which planned activities are carried out and planned results are achieved, it tells us about productivity as the relationship between the result achieved and the resources used, and the efficiency as a relationship between the result achieved and the resources used.

Performance indicators are measurements that are made in the different stages of the vital processes of the company in order to identify with the greatest objectivity possible the degree to which said stage is contributing or harming the achievement of strategic objectives. These stages range from the inputs that a company requires to function, through the internal processes of transformation of said inputs, until reaching the deliverables to the final customers.

For the application of the use of managerial indicators in industrial parks, it is necessary to carry out a questionnaire that is divided into 5 areas to analyze such as maintenance, administration, logistics, human resources and production, each of the areas contains in turn 10 indicators. which serve to know which ones are used by companies and which ones are not.

Below is the list of areas to analyze:

\section{Administration}

The administration department. It analyzes the processes, inputs and outputs, it also offers improvements in the company and, on the other hand, based on real numbers, it must know how to expose where it is possible to reduce costs and invest. In this way, you can increase your profits. It is not just a matter of keeping the documents up to date or of keeping the accounts well, but of having a broad vision of the company and showing areas for improvement.

The indicators of the administration area are:

- $\quad$ KPI administrative efficiency.

- KPI financial and budget information reports.

- KPI level of innovation of the company.
- $\quad$ KPI inventory turnover.

- $\quad$ KPI utility indices.

\section{Human Resources}

The task of this area is to carry out personnel planning, that is, to determine what is the need for labor that the company will have at a certain time, what type of profiles will be necessary, what type of contracts will be done and what will be its cost.

Its indicators are the following:

- $\quad$ KPI Growth rate on the learning curve.

- KPI Degree of satisfaction in KPI training courses.

- KPI Compliance with hours of training classes.

\section{- $\quad$ KPI Staff turnover.}

- KPI Effectiveness of advertising in personnel searches.

- $\quad$ KPI Average time of unfilled vacancies.

- KPI Absence rate.

- $\quad$ KPI Compensation or benefit ratio.

- KPI Contract cost.

\section{Production}

It is the area whose main function is the transformation of raw materials into final products. It has several levels or positions within its hierarchical structure such as workshop operators, workshop managers or team leaders, production manager or production manager, production engineers or specialized technical staff.

Its indicators are the following:

\section{- $\quad$ Returns KIP.}

- $\quad$ KIP of rejections.

- Unplanned rush production KIP.

- $\quad$ KIP raw material stock.

VAZQUEZ-GUTIERREZ, Rosa Inés, FLORES-AGUILAR, Mauricio and ARELLANO-YAÑEZ, Ricardo. Use of management indicators in the San Francisco de los Romo industrial park. Journal of Microfinance Planning and Control. 2020 
- $\quad$ KIP raw material inventory turnover.

- $\quad$ KIP machinery delays.

- $\quad$ KIP demand forecast errors.

- $\quad$ KIP of input requirements.

- KIP effectiveness in compliance.

- $\quad$ KIP delivery effectiveness.

\section{Logistics}

This area is in charge of carrying out the planning and control of all activities related to the obtaining, storage and transfer of materials, whether from the raw materials necessary in the first stages of the production process to the finished products that go directly to the client. final. follows:

The indicators of the logistics area are as

- KPI orders delivered with claims.

- KPI cost of unit stored.

- KPI clearance compliance level.

- KPI unit costs dispatched.

- KPI units separated or dispatched per employee.

- KPI urgent shipments.

- $\quad$ KPI deliveries on time (\%).

- $\quad$ KPI transportation costs (\%).

- $\quad$ KPI operating cost per driver.

- KPI purchase order fulfilment.

\section{Maintenance}

In this area, activities of a technicalorganizational nature are carried out to restore optimal operating conditions for equipment and machinery.
This measure may or may not be previously prepared according to a plan that ensures the constant work of the teams, in addition to establishing the needs of human, material, financial resources and the organizational structure to achieve the objectives set by the implemented system.

The indicators in the maintenance area are:

- KPI corrective maintenance ratio vs. preventive.

- KPI preventive maintenance tasks completed on date.

- KPI response time of maintenance department.

- KPI maintenance cost per square meter.

- KPI number of incidents resolved by first plant level.

- KPI hours used for production and unemployment.

- $\quad$ KPI availability for breakdowns.

- $\quad$ KPI corrective index.

- $\quad$ KPI material consumption.

\section{Results}

$75 \%$ of the companies surveyed in the San Francisco Industrial Park use administrative efficiency in kip, which is used to measure the cost to effectively manage each company of its average assets. $25 \%$ of companies do not implement this indicator.

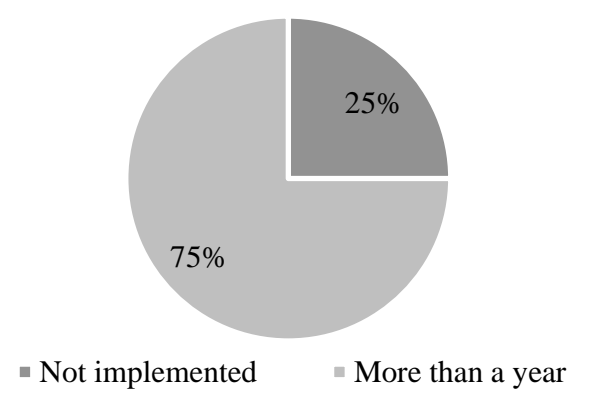

Graphic 1 Percentages of the administrative efficiency KIP 
In the KIP financial and budget information reports, its objective is to measure the capacity and efficiency to integrate the part of the expenses within the company, it was obtained as a result that $100 \%$ of the companies have implemented it for more than a year.

In the San Francisco Industrial Park, $100 \%$ of the companies use the company's innovation level kip, the metric to evaluate this indicator is new products / total products.

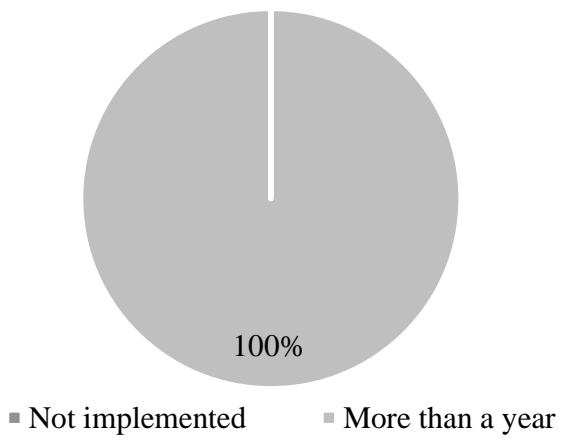

Graphic 2 Percentages of the company's innovation level KIP

$100 \%$ of the companies surveyed apply the inventory rotation KIP, which aims to measure how quickly various accounts are converted into sales or cash entries and exits.

The utility indices kip that allows knowing the net profits, $100 \%$ of the companies surveyed in the San Francisco Industrial Park implement this indicator, in addition to having more than a year of implementing it.

$75 \%$ of the companies in the San Francisco Industrial Park apply the KIP growth rate in the learning curve, its objective is to achieve a progressive improvement in the level of qualifications that indicate that employees have understood and accepted the knowledge imparted in the course. $25 \%$ of companies do not implement it.

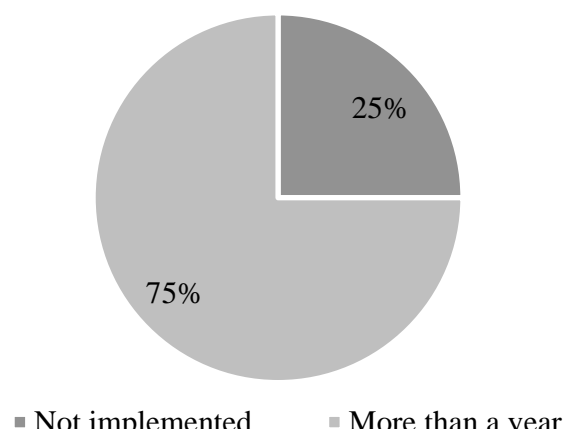

Graphic 3 Percentages of the KIP growth rate on the learning curve
The KIP degree of satisfaction in training courses seeks to know within the company what the employees who attend courses think about them. $50 \%$ of companies have more than a year to implement it and the other 50\% do not implement it.

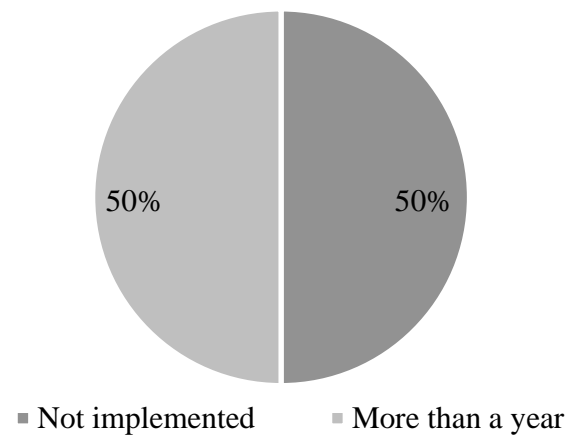

Graphic 4 Percentages of kip degree of satisfaction in training course

Of the companies surveyed in the San Francisco Industrial Park use the kip indicator, compliance with training class hours, its metric measures the number of class hours taken / number of class hours budgeted $x 100.25 \%$ of them implement it and $75 \%$ of them do not implement it.

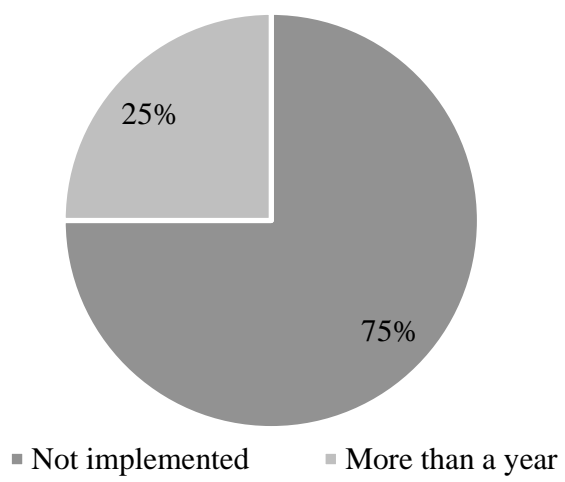

Graphic 5 Percentages of the kip compliance with training class hours

The companies surveyed, $100 \%$ use in kip staff rotation shows the degree of permanence of staff in the organization.

Of the companies consulted in the San Francisco Industrial Park, 50\% implement the advertising efficiency kip in personnel searches, this indicator measures the efficiency of advertisements. The other $50 \%$ of companies do not implement it. 


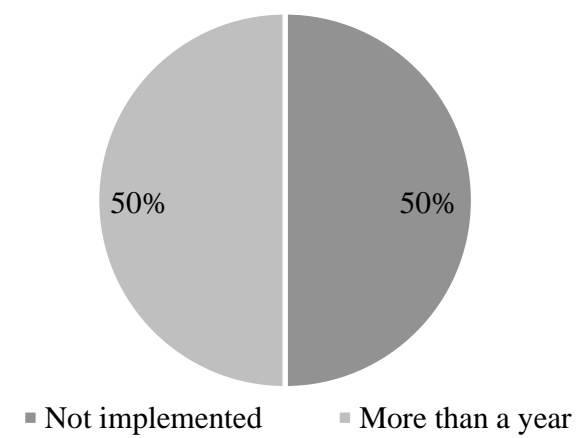

Graphic 6 Percentages of advertising efficiency kip in personnel searches

The KIP average time of unfilled vacancies, $25 \%$ of the companies surveyed use this indicator to measure the average time in which vacant positions are unfilled. $75 \%$ do not implement it.

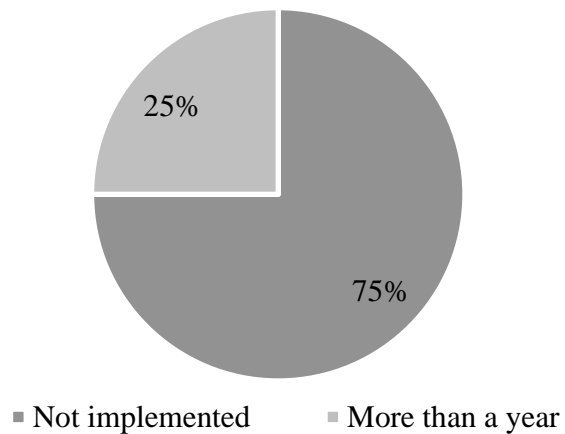

Graphic 7 Percentages of the average time kip of unfilled vacancies

$75 \%$ of the companies in the San Francisco Industrial Park implement the absence rate kip, this objective is to collect data, carry out calculations and present them at the appropriate time and form at all times. $25 \%$ of companies do not implement this indicator.

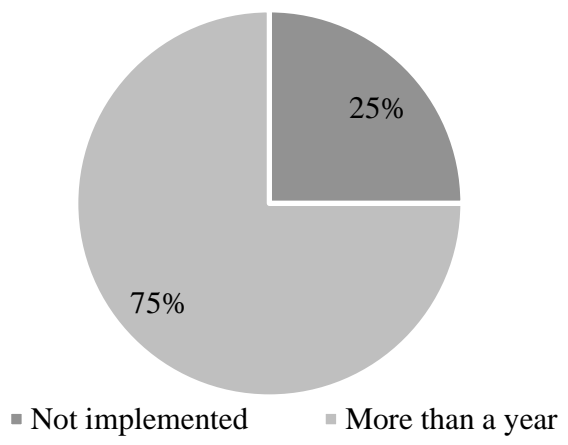

Graphic 8 Percentages of the absence rate KIP

$25 \%$ of companies use the compensation or benefit ratio kip to know the benefits and privileges that employees have for the performance of their work. $75 \%$ do not implement this indicator.
Of the companies surveyed, 25\% implement the hiring cost kip that allows evaluating the hiring costs / compensation cost + benefit costs, this indicator helps to know the personnel expenses in a company. $75 \%$ do not implement it.

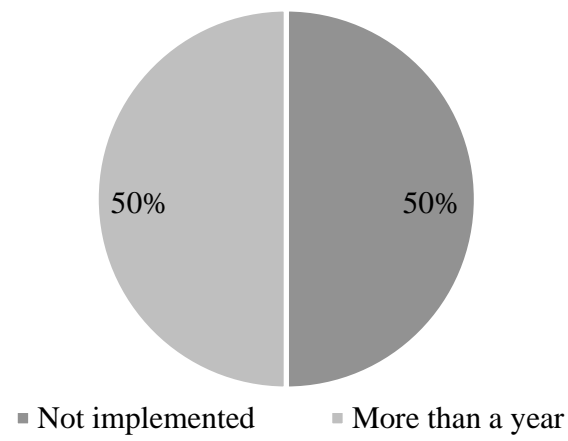

Graphic 9 Percentages of the hiring cost KIP

$100 \%$ of the companies surveyed in the San Francisco Industrial Park use the returns kip, its objective is to identify the product out of specifications and customer requirements. The rejection kip measures the quantity of products out of specification / quantity of inspected products. $75 \%$ of the companies apply it to evaluate the quality of the product. $25 \%$ do not implement this indicator.

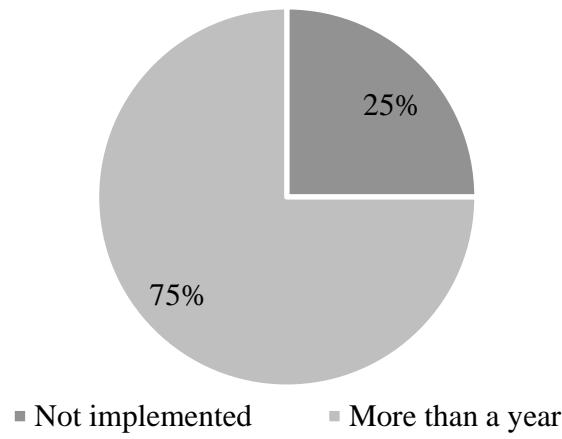

Graphic 10 Percentages of rejection KIP

$50 \%$ of the surveyed companies use the unplanned urgent production kip, it measures the amount of urgent production / total shipments $\mathrm{x}$ 100. Another $50 \%$ of the companies do not implement it. 


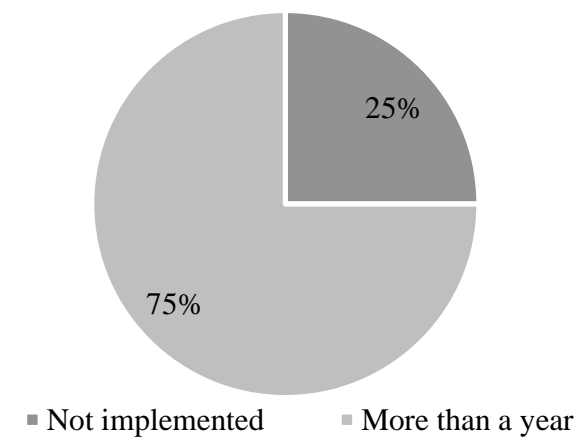

Graphic 11 Percentages of the unplanned urgent production KIP

$100 \%$ of the companies in the San Francisco Industrial Park use the KIP stock of raw materials to minimize costs within the company.

In the surveyed companies, it was obtained that $100 \%$ use the raw material inventory rotation KIP, this indicator helps companies to know the frequency with which purchases should be made and the minimum stock that the company must have.

Of the companies surveyed in the San Francisco Industrial Park, a percentage of $75 \%$ was obtained, which implement the machinery delay KIP; This indicator measures the stops of the equipment or process / time that should have occurred. $25 \%$ of companies do not implement it.

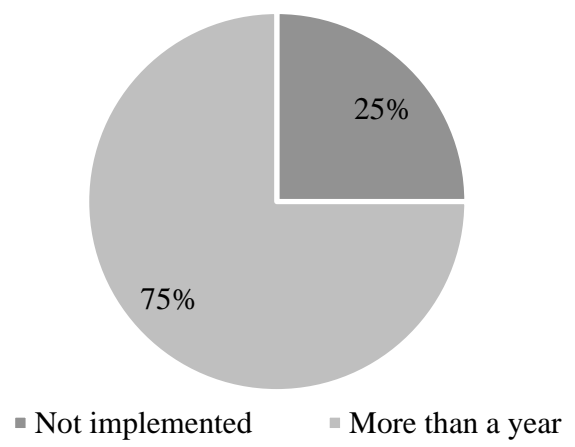

Graphic 12 Percentages of machinery delays KIP

$50 \%$ of the companies in the San Francisco Park use the kip demand forecast errors, this indicator takes into account the assertiveness of the forecasting method, measuring the real demand to the demand forecast / The real demand. Another 50\% do not implement it.

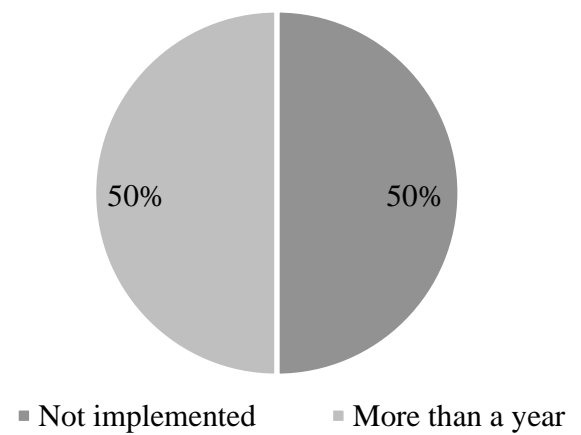

Graphic 13 Percentages of KIP demand forecast errors

$75 \%$ of the companies implement the kip of input requirements in the surveyed companies, this indicator allows to know the quantities of inputs that are needed to carry out their production process. $25 \%$ of companies do not implement it.

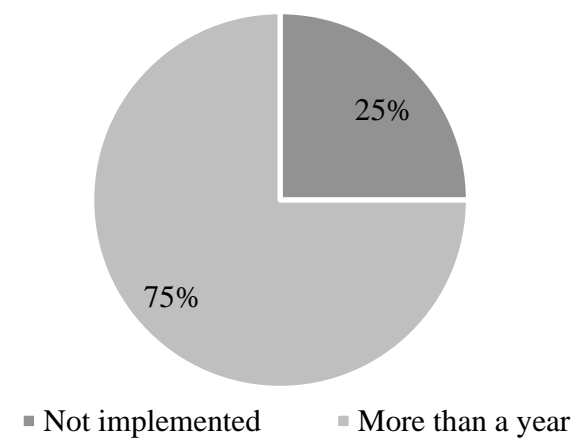

Graphic 14 Percentage of input requirements KIP

Of the companies interviewed in Parque San Francisco, $75 \%$ use the compliance effectiveness kip to measure the amount of production / Quantity that should have been produced, taking into account better customer satisfaction. $25 \%$ do not implement this indicator.

$100 \%$ of the companies in the San Francisco Industrial Park implement the delivery effectiveness KIP, this indicator allows companies to know if their product is not available at the time needed and cannot satisfy customer requirements.

Of the companies surveyed, $25 \%$ apply the kip orders delivered with claims of this indicator, its objective is to eradicate the causes of complaints due to damage to the products delivered. $75 \%$ implement it. 


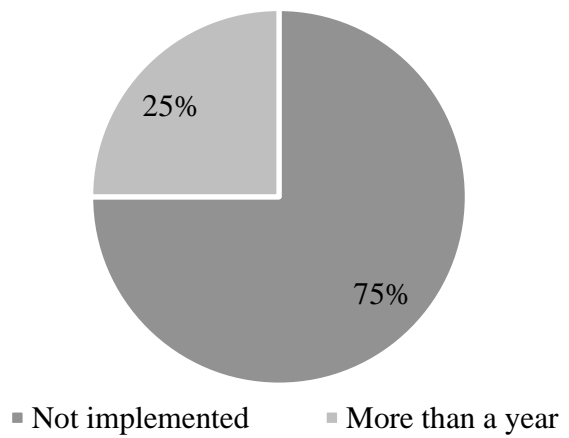

Graphic 15 Percentages of KIP orders delivered with claims

In the companies surveyed in the San Francisco Park, 50\% carry out the implementation of the stored unit cost KIP, this indicator measures. The cost of storage / Number of units stored. The other $50 \%$ of companies do not implement it.

$25 \%$ of companies implement the kip level of fulfillment dispatched, this indicator allows to know the level of effectiveness of merchandise dispatches to customers in terms of orders sent in a given period. $75 \%$ do not implement it.

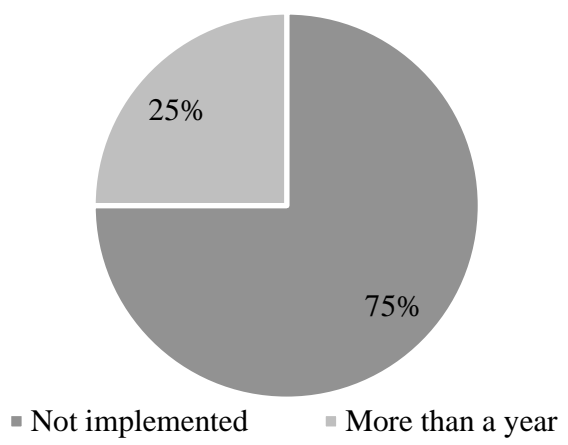

Graphic 16 Percentages of the KIP level of compliance dispatched

In the companies surveyed, $50 \%$ have been implementing the dispatched unit cost kip for more than a year, this indicator measures the Warehouse Operation Cost / Total units dispatched. $50 \%$ of companies do not implement it.

$25 \%$ of the companies use the kip units separated or dispatched per employee, this indicator allows to know the number of units dispatched or boxes for each employee of the total dispatched. $75 \%$ of companies do not implement it.

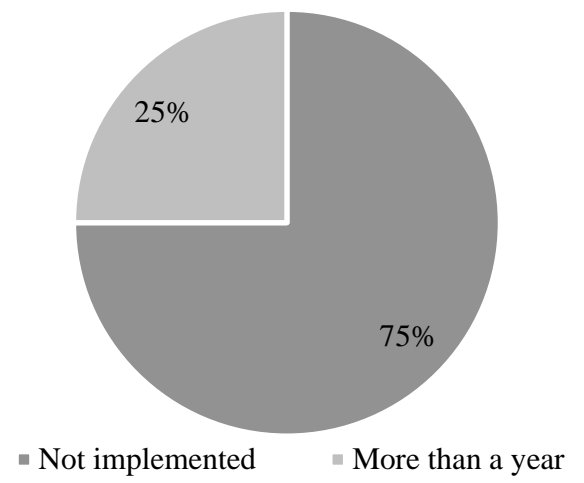

Graphic 17 Percentages of the KIP units separated or dispatched per employee

$50 \%$ of the companies in the San Francisco Industrial Park have been applying the kip urgent shipments for more than a year. This indicator makes it easier for them to measure the Quantity of urgent shipments / Amounts of total shipments. The other 50\% do not implement it.

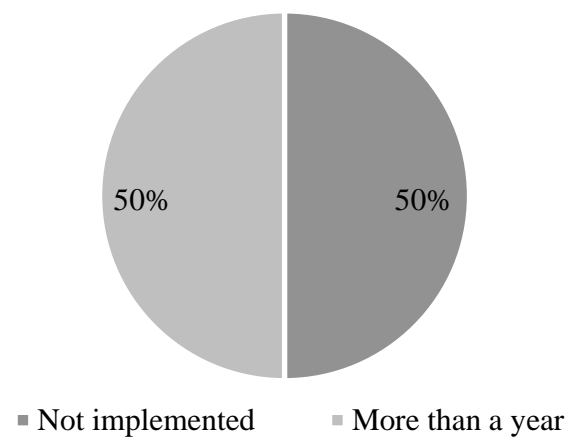

Graphic 18 Percentages of kip urgent shipments

$50 \%$ of the surveyed companies apply the kip deliveries on time, this indicator corresponds to the level of compliance of the supplier, for the delivery of orders on the date or period of time agreed with the client. Another 50\% of companies do not implement this indicator.

The surveyed companies indicated that they apply the transportation cost kip. 50\% have implemented it for more than a year, the other $50 \%$ do not implement it. The objective of this indicator is to control the cost of transportation in relation to the company's sales.

The KIP Indicator operating cost per driver is applied by $50 \%$ of the surveyed companies, managing to control the contribution of each driver within the total transportation expenses. The other $50 \%$ do not implement it. 
In the San Francisco Industrial Park, $100 \%$ of the companies carry out the application of the purchase order fulfillment kip.This indicator helps to measure the sum of the purchase order cycles / total \# of purchase orders.

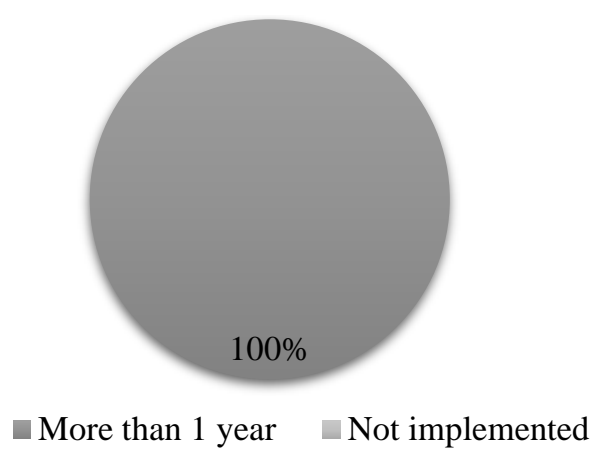

Graphic 19 Percentages of the purchase order fulfillment KIP

The corrective maintenance vs. that aims to control the preventive maintenance policy as a general improvement and cost reduction system, $75 \%$ of the surveyed companies of the San Francisco Industrial Park apply it and have implemented it for more than a year and $25 \%$ do not implement this indicator.

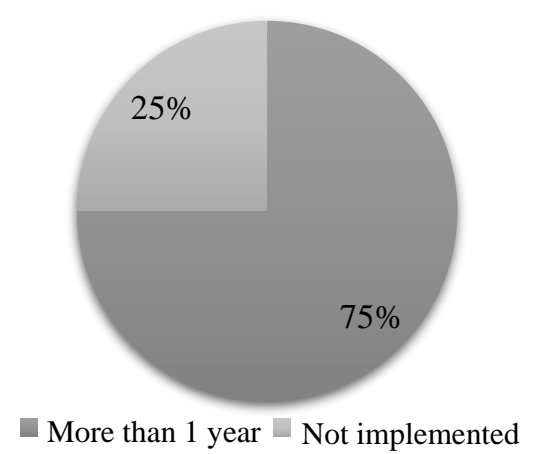

Graphic 20 Percentages of KIP corrective maintenance relationship vs. Preventive

Of the companies surveyed, $50 \%$ have been implementing the maintenance department response time kip for more than a year, this indicator measures the speed of response of the maintenance area. The other $50 \%$ do not implement it.

The maintenance cost per square meter kip, 25\% of companies have been implementing this indicator for more than a year, their main objective is to keep maintenance costs under control. $75 \%$ of companies do not implement it.

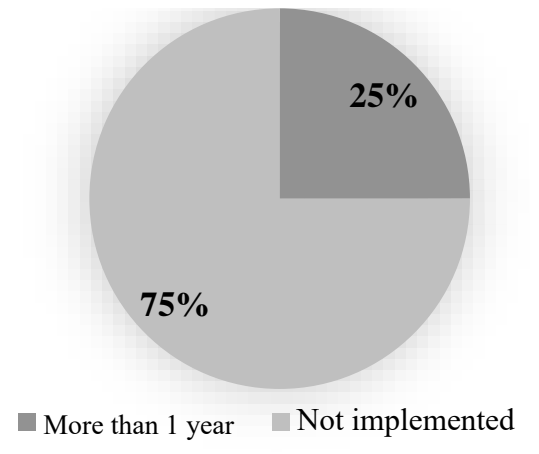

Graphic 21 Percentages of maintenance cost KIP per square meter

The companies surveyed in the San Francisco Industrial Park do not apply the kip number of incidents resolved by the first level of the plant. This indicator measures the Number of incidents resolved by PNP / Total number of reported incidents $\mathrm{x} 100$.

The kip hours used for production and those of unemployment, in the companies surveyed in the San Francisco Park, 75\% apply this indicator that serves to draw the sample between the hours used for production and those of equipment stoppage due to breakdowns. $25 \%$ do not implement this indicator.

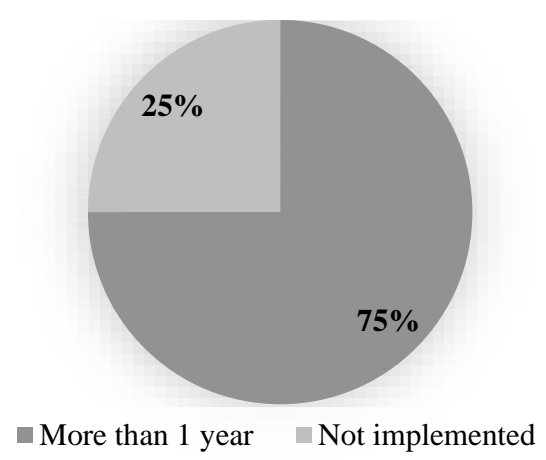

Graphic 22 Percentages of KIP hours used for production and unemployment

The KIP availability indicator for breakdowns which helps to measure Total Hours - Breakdown Hours / Total Hours, 50\% of companies have been implementing this indicator for more than one year. The other $50 \%$ do not implement it.

$100 \%$ of the companies have been implementing this corrective index kip for more than a year, which measures the Hours dedicated to corrective maintenance / Total hours dedicated to maintenance. 


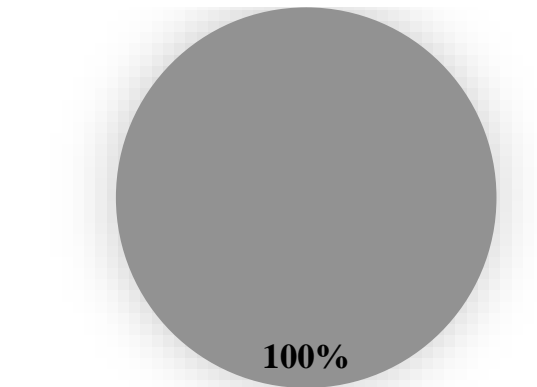

$\square$ More than 1 year $\square$ Not implemented

Graphic 23 Percentages of the corrective index KIP

$50 \%$ of the companies surveyed in the San Francisco Park implement the material consumption kip as it helps them measure the consumption of spare parts and consumables in their own maintenance activities in relation to the total consumption of materials. Another 50\% do not implement it.

\section{Conclusions}

The following was found in the indicators:

- Administration.

$100 \%$ implementation of all indicators is met, except for administrative efficiency, which has only been implemented in $75 \%$ of companies, which indicates quite acceptable progress in this area of consolidation of the Business.

The above represents $80 \%$ of the indicators met.

- Human Resources.

In the indicators of growth rate in the learning curve and absence rate, they present an implementation percentage of $75 \%$ against $25 \%$ of companies that have not yet contemplated it.

On the other hand, in the indicators of: the degree of satisfaction in training courses and the efficiency of advertising in personnel searches show a percentage of implementation of $50 \%$ against $50 \%$ of companies that have not yet completed it.
In addition, in the indicators of: compliance with hours of training classes, average time of unfilled vacancies, compensation or benefit ratio and hiring cost, they show a percentage of completion of $25 \%$ against $75 \%$ of companies that have not yet done so. completed.

In this area, $22.2 \%$ of the defined indicators are met.

- Production.

In this area, the indicators that comply with $100 \%$ are:

Returns, raw material stock process, the rotation of raw material inventory and finally the delivery effectiveness.

On the other hand, the indicators in which the companies have been attended by $75 \%$ are:

Indicators of rejections, machinery delays, input requirements and effectiveness in compliance.

On the other hand, the indicators that have been implemented by $50 \%$ are:

Unplanned urgent production and demand forecast errors.

Here $50 \%$ of the indicators are achieved.

- Logistics.

In this section, $100 \%$ compliance has been in the purchase order indicator.

Instead, the indicators:

Cost of stored unit, urgent shipments, ontime deliveries (\%), transportation costs (\%) and operating cost per driver have only been reached by $50 \%$ of companies.

With only $25 \%$ follow-up, the indicators are presented:

Orders delivered with claims, level of fulfillment dispatch, unit dispatched costs, and separate units or dispatched per employee. 
For this section, only $10 \%$ of the indicators are met

- Maintenance.

In this last area, $100 \%$ is reached only in the corrective index indicator.

In the corrective maintenance vs. prevention and hours used for production and unemployment are reached by $75 \%$ of companies.

$50 \%$ of scope is presented by companies in the indicators: response time of the maintenance department, availability due to breakdowns and consumption of materials

In particular, $25 \%$ of companies contemplate implementing maintenance costs per square meter

Furthermore, no company has developed and implemented the indicator for the number of incidents resolved by the first plant level.

\section{Recommendations}

Based on the indicators shown, a risk analysis process is suggested for each area in order to determine the actions to take to achieve the implementation of the indicators in their entirety, since the lack of implementation of indicators impacts both on the development of companies as well as in the value chain for end customers.

\section{Acknowledgments}

We appreciate the collaboration of the student Paulina de la Rosa Sánchez, as well as that of the UTNA authorities who supported us to carry out this research.

\section{References}

Anaya Tejero, J. (2007). Organizacion de la producción industrial. Esic Editoria.

Ads Quality. (2002) Enciclopedia de la Calidad. España.

Biblioteca de KPI (Indicadores Clave). Obtenido de https://www.sixtinagroup.com/biblioteca-deindicadores/ (Mayo de 2019).
Chirinos, O. (2008). Indicadores de la gestión para medir la eficacia. Uso de indicadores en las empresas, 63.

De Elian, G. (2006). Indicadores de calidad y productividad en las empresas. Argentina: Alsina.

Gutiérrez Pulido, Humberto. (2010).Calidad Total y Productividad México, D.F.: McGrawHill Education.

Hernández Sampieri, Roberto. Metodología de la investigación México, D.F.: McGraw-Hill, 2010.

INEGI. (2018). Directorio Estadístico Nacional de Unidades Económicas (DENUE).

Mark Davidson, L. (9 de Enero de (2013). Indicadores de producción. Obtenido de https://www.lifeder.com/indicadoresproduccion/

Marlin, A. (12 de Febrero de 2007). Indicadores financieros y de gestión. Obtenido de https://incp.org.co/Site/2012/agenda/7-if.pdf

Mora Garcia, L. (2008). Indicadores de la gestión logística. México: 2da Ed.

Sánchez Quintero, J. (2014). Indicadores de la calidad. Estudios Gerenciales, 429.

Schermerhorn. (2006). Administración. México: Limusa S.A de C.V.

Villagra Villanueva, J. ((2016)). Indicadores de gestión. México: (1era Ed.). 